\title{
Hypnosis as a part of holistic medical treatment: a systematic review
}

\author{
Hipnoza jako element całościowej terapii medycznej: systematyczny przegląd \\ literatury
}

\author{
Marcin Żelezik, Marcin Sadowski \\ Faculty of Medicine and Health Sciences, Jan Kochanowski University in Kielce
}

Neuropsychiatria i Neuropsychologia 2020; 15, 1-2: 21-32

Address for correspondence:

Marcin Żelezik

Faculty of Medicine and Health Sciences

Jan Kochanowski University

IX Wieków Kielc 19 A Avenue, 25-317 Kielce

e-mail: marcinzelezik@gmail.com

\section{Abstract}

Aim of the study: Analysis of the worldwide reports about possibilities and current usage of hypnosis in conventional medicine.

Material and methods: A systematic literature search has been conducted on the PubMed database for meta-analyses and clinical trials. A total of 196 full-text articles were screened. The inclusion criteria, such as hypnosis had to be used in medical procedures as the main method of therapy, the study was either a randomized controlled trial (RCT) or clinical trial, there were measures of the effect of hypnosis and the intervention was compared to either other psychological intervention, standard treatment or placebo, were covered by 13 articles. The Google Scholar search engine was used to extract additional materials for explanatory reasons.

Results: The use of hypnosis has been found in several fields of medicine, mainly in pediatrics and gastroenterology. It was mostly used to elevate patients' life quality by lowering or eliminating pain, distress, depression, and anxiety. It has been found that hypnosis was used also in more complex procedures such as anesthesia or accelerating wound healing.

Conclusions: It is crucial for current medical practice not to underestimate the possibilities of a beneficial outcome for hypnosis use in different medical conditions. Overall strong evidence was provided that hypnosis is not a form of charlatanry, but an evidence-based medical procedure.

Key words: hypnosis, pain, patients, treatment, suggestion.

\section{Introduction}

Not until 1986 can we see any growth in interest in the field of hypnosis used in medicine. Since then, after the constant growth of publica-

\section{Streszczenie}

Cel pracy: Analiza ogólnoświatowego piśmiennictwa dotyczącego możliwości i obecnego zastosowania hipnozy w medycynie.

Material i metody: Przeprowadzono systematyczny przegląd literatury w bazie PubMed $\mathrm{z}$ uwzględnieniem metaanaliz i badań klinicznych. Całkowita liczba przejrzanych pełnych tekstów wynosiła 196. Kryteria włączenia - hipnoza została użyta w procedurze medycznej jako jedna z głównych metod terapii, artykuł był metaanalizą lub badaniem klinicznym $z$ randomizacją lub bez, wyniki interwencji były mierzone i porównywane $z$ inną interwencją psychologiczną, terapią standardową lub placebo - spełniło 13 artykułów. Do wyjaśnienia niektórych pojęć, opierając się na źródłach naukowych, użyto wyszukiwarki Google Scholar.

Wyniki: Hipnoza była stosowana w wielu gałęziach medycyny, jednak znacząca część doniesień traktowała o wykorzystaniu jej w pediatrii i gastroenterologii. Głównym celem użycia hipnozy było podniesienie jakości życia pacjentów przez zmniejszenie lub uśmierzenie bólu, stresu, niepokoju i depresji. Znaleziono również doniesienia o wykorzystaniu hipnozy w bardziej złożonych procedurach, takich jak znieczulenie i przyspieszenie gojenia ran.

Wnioski: Dla obecnej praktyki medycznej istotne jest zaprzestanie niedoceniania możliwości pozytywnego wpływu hipnozy w różnych sytuacjach medycznych. W pracy przedstawiono silne argumenty potwierdzające, że hipnoza nie jest formą szarlatanerii, ale procedurą opartą na dowodach naukowych.

Słowa kluczowe: hipnoza, ból, pacjenci, leczenie, sugestia.

tions, there has been a rapid pick of interest from 2013 until now. Hence we assume that hypnosis is a point of interest of a growing number of researchers because of the possibilities it promises. This paper aims to provide an overview 
of the field, for future reference for clinicians and researchers interested in it who are new to the topic of hypnosis used in medicine.

The history of hypnosis may be helpful in understanding this state of facts. It starts long in ancient times, as there was found an Egyptian papyrus, over 3000 years old, describing how Egyptian soothsayers used hypnotic techniques, similar to those used today. There are many allusions to the use of hypnosis in the Talmud and the Bible as there can be found a variety of prayer and touch healings (Tyrer 2013). But the most significant name in the history of hypnosis is Franz Anton Mesmer, who after graduating from medical school made a hypothesis that every organism has its own flow of "magnetic fluids" and therefore the illness is a state in which those fluids are improperly arranged. He began to practice so-called "magnetism", which was a series of movements of magnets performed by him over his patient. Medical society at that time was very skeptical about this concept and because of that, Mesmer was called a charlatan. But from that moment, from 1784, many physicians were interested in "magnetism" and were experimenting with that method. During that time, a new concept arose, which was "hypnoanalgesia". This was popularized by James Esdaile, who began using "mesmerism", which was actually a classical form of hypnosis, as a form of anesthesia during surgery. He noticed that not only the pain was lowered, but also the mortality during the surgery - from $50 \%$ to $5 \%$. After that time, in the 1870s, hypnosis enjoyed a period of tremendous growth because of clinicians such as Broca (Schiller 1979), Charcot (Owen 1971) and Freud (Kroger 2008) (Hammond 2013).

We want to emphasize the possibilities of hypnosis in the medical field by showing its most current use in many areas of medicine. We hope that after reading that paper members of the medical society will be more attracted to the use of this tool in their practice.

By hypnosis, we mean "a state of consciousness involving focused attention and reduced peripheral awareness characterized by an enhanced capacity for response to suggestion" (Elkins et al. 2015) and it is achieved by use of suggestions and hypnotic induction, which is the sequence of activities which minimize the influence of the distractors and convince hypnotized people to focus only on suggested feelings and that they will enter the particular state of deep relaxation.

Therefore it is necessary to know that not everyone is hypnotizable to the same extent and in some cases, one simply cannot respond (Maldonado and Spiegel 2015). Another limitation of the method is the fact that it is hard to reliably and reproducibly measure or conduct a doubleblind clinical study involving hypnosis. That is primarily because of individual variability and secondly due to the methodology of hypnosis techniques (Wobst 2007).

On the other hand, there are two psychological tests to measure how deeply the patient is in a state of hypnosis. Those are Stanford Hypnotic Susceptibility Scale, the Harvard Group Scale of Hypnotic Susceptibility and the Hypnotic Induction Profile (Hoeft et al. 2012; Keuroghlian et al. 2010; Stern et al. 1978). Also, with the use of functional magnetic resonance imaging (fMRI) (Häuser et al. 2016) and electroencephalography

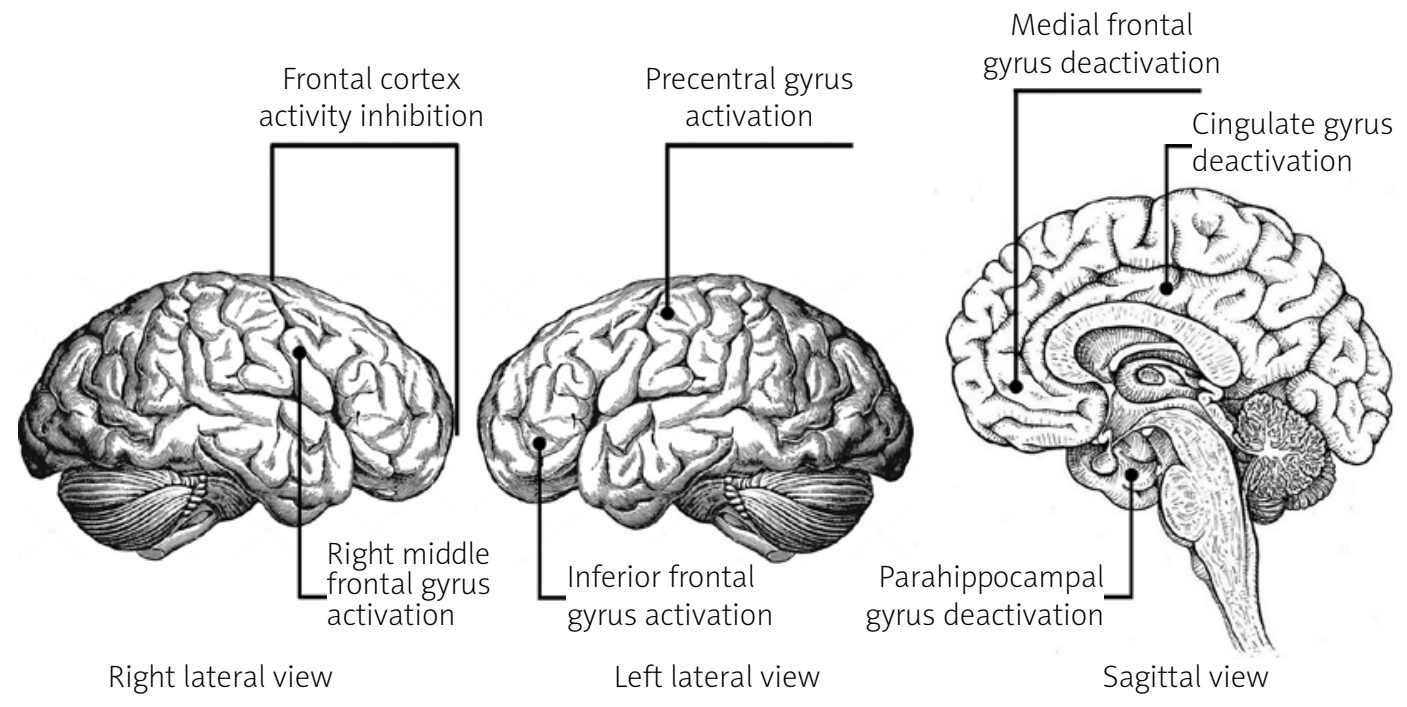

Fig. 1. Changes in brain activity during hypnosis 
(EEG) (Eskandari et al. 2017), several changes in the brain can be observed. There is activation in the inferior frontal gyrus and prefrontal gyrus (Nash and Barnier 2008). The right hemisphere cortex is activated and frontal cortex activity is inhibited. There is also observed deactivation in the "default mode network (DMN), which consists of the medial prefrontal cortex, superior frontal cortex, and the anterior and posterior cingulate cortex" (Kihlstrom 2013).

In this paper, we want to present what has been done in the field of medical hypnosis, how patients' state can be controlled and in which interventions there is evidence of successful use and in which there is a need for further research. We want to emphasize the importance of comparison of the hypnotic intervention to no intervention and the clinical importance of outcomes of those studies (Fig. 1).

\section{Material and methods}

\section{Data sources}

For the purpose of this systematic survey of the literature, the most recent articles on hypnosis and books available were studied. The PubMed database has been searched for articles matching inclusion criteria and the Google Scholar search engine was used to find additional materials needed for explanatory reasons. The search was done on 15 November 2018.

\section{A systematic review}

Reviews were eligible for inclusion if 1) hypnosis was used as a method or procedure and it was not a synonym of sleep, but a phenomenon of an alternative state of consciousness, 2) hypnosis was used before, during or after medical procedures as a main component of the therapy, 3) studies were either randomized controlled trials (RCTs) or clinical trials (CTs), 4) the effect of hypnosis use was assessed in comparison with a different method/form of therapy or placebo, 5) hypnosis was used on patients experiencing pain, anxiety, awaiting an operation or under any other medical condition, excluding dental conditions, as there are more profound articles on strictly that topic, 6) the article was published in English or Polish language. There were no restrictions on age, sex, country, etc. If duplicates of the study in terms of methods were found, we took the one with the greatest number of patients participating.

The following search terms were used: "clinical trial", "review", "meta-analysis", and "hypnosis". PubMed was searched with ((hypnosis

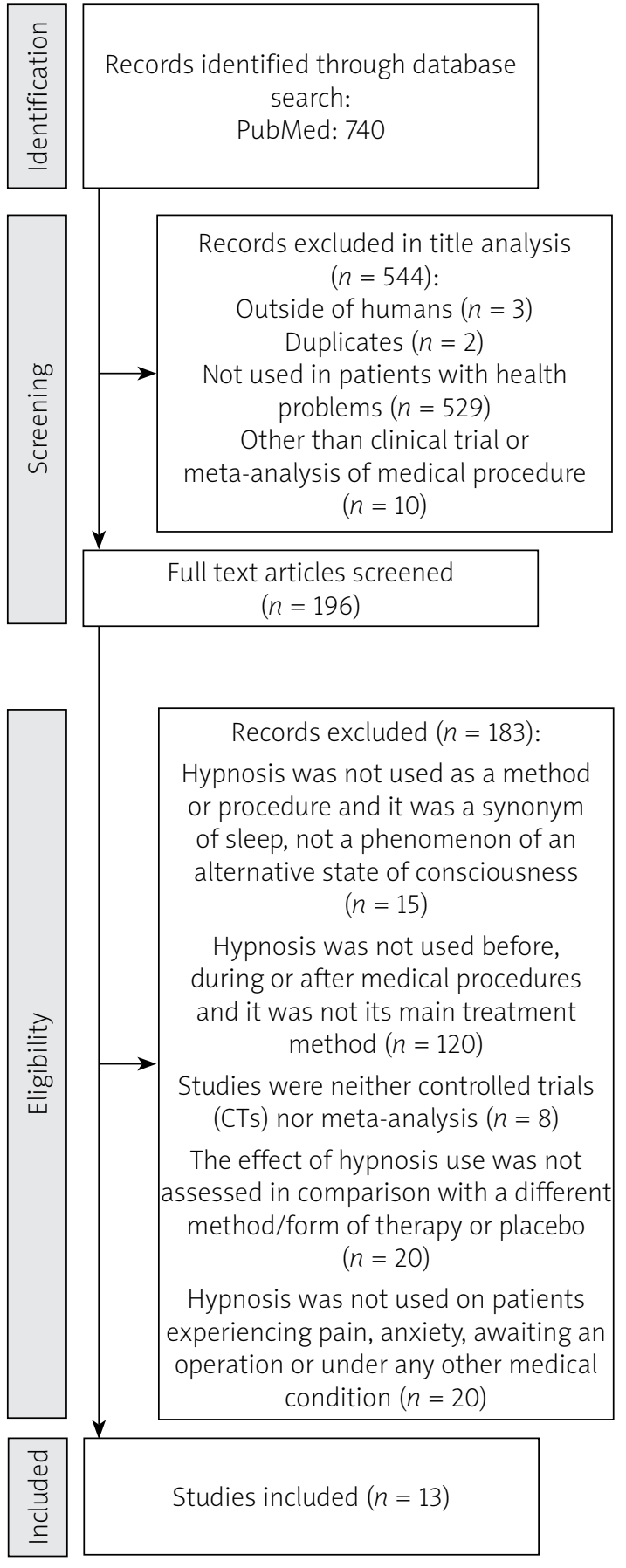

Fig. 2. Preferred reporting items for systematic reviews and meta-analyses

[MeSH Terms]) AND (meta-analysis [publication type] OR clinical trial [publication type] NOT review [publication type])).

Meta-analyses found were used as a guide to including more valuable original papers meeting the inclusion criteria.

\section{Results}

From a total of 742 items from the PubMed database, a total of 196 full texts were screened. 
Table 1. Included articles

\begin{tabular}{|c|c|c|}
\hline Article & Purpose of hypnosis use & Study type \\
\hline $\begin{array}{l}\text { Ter Kuile } \\
\text { et al. } 1994\end{array}$ & $\begin{array}{l}\text { Researchers studied } 136 \text { patients to find out if autogenic training (AT) and cognitive self-hyp- } \\
\text { nosis training }(\mathrm{CSH}) \text { are valuable for chronic headaches. } 40 \text { of them received CSH treatment, } \\
41 \text { autogenic training and } 53 \text { a waiting list period. Headache intensity was measured using } \\
\text { the headache index. There was a significant main effect of the pain intensity decreasing with } \\
\text { the intervention }(F(124,2)=5.8, p=0.004) \text {, but there was no significant difference between } \\
\text { the forms of therapy. }\end{array}$ & $\mathrm{RCT}$ \\
\hline $\begin{array}{l}\text { Zitman } \\
\text { et al. } 1992\end{array}$ & $\begin{array}{l}79 \text { patients were randomly assigned a therapy, either autogenic training (AT) }(n=28) \text { or futu- } \\
\text { re-oriented hypnotic imagery }(\mathrm{FI})(n=27) \text { and a therapist for the treatment of tension heada- } \\
\text { ches. Moreover, in the second phase of the study, patients were presented the Fl intervention } \\
\text { as "hypnosis" }(\mathrm{FI}-\mathrm{H})(n=24) \text { to determine whether that would influence the efficacy of the } \\
\text { method. On } 66 \text { patients who completed the } 6 \text {-month follow-up period, there was a signifi- } \\
\text { cant interaction effect between therapy and time on headache index score } F(4,120)=3.31 \text {, } \\
p<0.05) \text {. Moreover, patients with Fl-H intervention showed a greater reduction in their heada- } \\
\text { ches compared to the pre-treatment assessment than the AT group. No significant differences } \\
\text { in anxiety and depression were found between the therapy methods. }\end{array}$ & $\mathrm{RCT}$ \\
\hline $\begin{array}{l}\text { Montgo- } \\
\text { mery et al. } \\
2017\end{array}$ & $\begin{array}{l}\text { The authors measured the impact of cognitive-behavioral therapy plus hypnosis (CBTH) on } \\
\text { emotional distress in women undergoing breast cancer radiotherapy. The intervention group, } \\
n=50 \text {, was compared to the group treated with standard attention control (AC) } n=50 \text {. Most } \\
\text { results were seen at conclusion of radiotherapy or 4-week follow-up that included lower scores } \\
\text { in a short version of the Profile Mood States, Tension-Anxiety, Depression-Dejection, Anger-ho- } \\
\text { stility, Vigor-Activity and Fatigue-Inertia in the CBTH group in comparison with AC group. }\end{array}$ & $\mathrm{RCT}$ \\
\hline $\begin{array}{l}\text { Schnur } \\
\text { et al. } 2008\end{array}$ & $\begin{array}{l}\text { Ninety patients presenting for excisional breast biopsy were randomly assigned to receive } \\
\text { either a } 15 \text {-minute presurgery hypnosis session or } 15 \text {-minute presurgery attention control } \\
\text { session. Suggestions given in hypnosis involved increased relaxation and decreased distress } \\
\text { and control group of attention control involved nondirective empathic listening. The authors } \\
\text { reported that after intervention and before surgery patients in the hypnosis group had signifi- } \\
\text { cantly lower visual analog scales (VAS) emotional upset mean values ( } 16.5 \text { vs. } 38.2, p<0.0001 \text {, } \\
d=0.85 \text { ), VAS depressed mood ( } 6.6 \text { vs. } 19.9, p<0.02, d=0.67) \text {, and SV-POMS anxiety }(10.0 \\
\text { vs. } 5.0, p<0.0001, d=0.85) \text {; and significantly higher levels for VAS relaxation ( } 75.7 \text { vs. } 54.2 \text {, } \\
p<0.001, d=-0.76 \text { ) than attention controls. }\end{array}$ & $\mathrm{RCT}$ \\
\hline $\begin{array}{l}\text { Stalpers } \\
\text { et al. } 2005\end{array}$ & $\begin{array}{l}69 \text { patients receiving radiotherapy (RT), mostly because of breast or prostate cancer, were ran- } \\
\text { domly assigned to either the control group or intervention of hypnotherapy focused on decreas- } \\
\text { ing levels of their anxiety and quality of life. Researchers found that there was no statistically } \\
\text { significant difference between the groups in terms of anxiety levels and quality of life }(p=0.96) \text {. } \\
\text { Mental and Physical Component score was measured. There was no significant difference in } \\
\text { these scores ( } p=0.582) \text { between the hypnotherapy and control group, although it was pointed } \\
\text { out that } 17 \text { of the } 33 \text { patients in the hypnotherapy group stated that they improved their mental } \\
\left.\text { well-being ( } \chi^{2} 0.95=22.319, p<0.05\right) \text { in comparison with the control group, where none of them } \\
\text { stated the same. } 18 \text { of the patients from the hypnotherapy group and } 4 \text { in the control group } \\
\text { indicated an improvement in overall well-being }\left(\chi^{2} 0.95=17.916, p<0.05\right) \text {. }\end{array}$ & $\mathrm{RCT}$ \\
\hline $\begin{array}{l}\text { Marc et al. } \\
2008\end{array}$ & $\begin{array}{l}347 \text { patients were randomized and given anxiety and pain care, either standard or using hyp- } \\
\text { nosis. Patients were women, aged } 18-46 \text {, who were undergoing first-trimester pregnancy ter- } \\
\text { mination surgery. The group with the hypnosis session given, } n=172 \text {, was treated by one of } \\
2 \text { certified hypnotists with the standardized hypnotic intervention (SHI). The group with stan- } \\
\text { dard care given, } n=172 \text {, stayed in the room with their relative or friend for } 20 \text { min prior the } \\
\text { intervention, then went to the operating room with the family planning nurse who provided } \\
\text { the usual attention and support to the patient. The } 22 \% \text { difference ( } 95 \% \mathrm{Cl}: 13-32 \% \text { ) in the use } \\
\text { of medication was statistically significant, which means that } 4-5 \text { patients (number needed } \\
\text { to treat, } 5 \text {; } 95 \% \mathrm{Cl} \text { : } 3-8 \text { ) would have to receive the } \mathrm{SHI} \text { for } 1 \text { person to benefit from it and not } \\
\text { require sedation during the procedure. The difference between pain in both groups met stati- } \\
\text { stical significance (difference, } 2.43 \text {; } 95 \% \text { inferior } \mathrm{Cl}=-2.28 \text {, } 1 \text {-sided } p=0.0048 \text {, null hypothesis } \\
\text { rejected). However, the difference in anxiety was not statistically significant. }\end{array}$ & RCT \\
\hline $\begin{array}{l}\text { Lang et al. } \\
2008\end{array}$ & $\begin{array}{l}201 \text { patients undergoing percutaneous tumor embolization received either standard care, em- } \\
\text { phatic attention or self-hypnotic relaxation. The patients received a local anesthetic ( } 2 \mathrm{mg} \\
\text { hydromorphone s.c.). The authors reported that anxiety decreased significantly in the hyp- } \\
\text { nosis group compared to the standard group in the first } 15-30 \text { min and by } 30-45 \text { min anxiety } \\
\text { in the hypnosis group was significantly decreased as compared to the standard and also the } \\
\text { empathy group. The pain was significantly less for hypnosis than standard and empathy pa- } \\
\text { tients in the } 15-30 \text { and } 30-45 \text { min intervals. Moreover, patients in the hypnosis group received } \\
\text { significantly less medication (mean }=2.00 \text {, IQR }=1-4 \text { ) than standard group patients (mean } \\
=3.00, I Q R=1.5-5.0, p=0.0147 \text { ) and empathy group patients (mean }=3.50, I Q R=2.0-5.9 \text {, } \\
p=0.0026 \text { ), who did not differ from each other }(p=0.4505) \text {. }\end{array}$ & $\mathrm{RCT}$ \\
\hline
\end{tabular}


Table 1. Cont.

\begin{tabular}{|c|c|c|}
\hline Article & Purpose of hypnosis use & Study type \\
\hline $\begin{array}{l}\text { Abramo- } \\
\text { witz et al. } \\
2008\end{array}$ & $\begin{array}{l}\text { The benefits of add-on hypnotherapy in patients with chronic posttraumatic stress disorder } \\
\text { (PTSD) were assessed. Thirty-two PTSD patients treated with SSRI antidepressants and sup- } \\
\text { portive psychotherapy were randomized to } 2 \text { groups: } 15 \text { patients in the first group received } \\
\text { zolpidem } 10 \text { mg nightly for } 14 \text { nights, and } 17 \text { patients in the hypnotherapy group were treated } \\
\text { with symptom-oriented hypnotherapy, twice-a-week } 1.5 \text {-hour sessions for } 2 \text { weeks. After the } \\
\text { duration of the therapy, there was a significant main effect in the treatment group, } F(1,30)= \\
4.96, p=0.034 \text {, with PTSD symptoms as measured by the PDS being lower in the hypnothe- } \\
\text { rapy group (HT) compared to the zolpidem group (ZT). This effect was preserved at follow-up } \\
1 \text { month later. The authors also reported that there was a significant positive effect of hypnosis } \\
\text { on decreasing depression, improving sleep in its overall score but also in quality and in decre- } \\
\text { asing the number of awakenings. }\end{array}$ & RCT \\
\hline $\begin{array}{l}\text { Liossi et al. } \\
2006\end{array}$ & $\begin{array}{l}\text { A prospective controlled trial on } 45 \text { patients (age } 6-16 \text { years). The study compared the impact } \\
\text { on lumbar puncture-induced pain and anxiety of an analgesic cream (eutectic mixture of local } \\
\text { anesthetics, or EMLA) with a combination of EMLA with hypnosis. For the purpose of compari- } \\
\text { son, patients were divided randomly into } 3 \text { groups: EMLA only, EMLA plus hypnosis, EMLA plus } \\
\text { attention control. For the self-reported anticipatory anxiety, there was a statistically significant } \\
\text { difference between the EMLA hypnosis and the EMLA groups. A similar effect could be obse- } \\
\text { rved in procedure-related self-reported anxiety levels where the mean self-reported anxiety in } \\
\text { the EMLA attention group was significantly lower than the mean in the EMLA group and there } \\
\text { was a significantly lower mean for the EMLA hypnosis group compared with the EMLA group. } \\
\text { Moreover, the mean level of procedure-related pain in the EMLA hypnosis group was found } \\
\text { to be lower than that in the EMLA attention group. The results confirmed that patients in the } \\
\text { local anesthetic plus hypnosis group reported less anticipatory anxiety and less procedure- } \\
\text {-related pain and anxiety and that they were rated as demonstrating less behavioral distress } \\
\text { during the procedure. }\end{array}$ & RCT \\
\hline $\begin{array}{l}\text { Mauer } \\
\text { et al. } 1999\end{array}$ & $\begin{array}{l}60 \text { patients presenting for hand surgery in Hand Service at the Ryder Trauma Center, Miami, } \\
\text { Florida, where } 30 \text { of them were assigned to receive hypnotic treatment consisting of } 20 \text { min } \\
\text { of the Rapid Induction of Analgesia (RIA) script modified to fit present sample, context, and } \\
\text { research questions. The control group, } n=30 \text {, received standard attention control care. There } \\
\text { was a measure of Perceived Pain Intensity (PPI), Perceived Pain Affect (PPA) and State-Anxiety } \\
\text { (SANX). Hypnosis group patients had reported lower PPA and PPI than the control group for } \\
\text { all } 3 \text { posttreatment days and additionally lower SANX on day } 4 \text {. The authors suggested that } \\
\text { their work shows not only the beneficial impact of hypnosis on perceived pain but also its } \\
\text { significant influence on the process of healing. }\end{array}$ & RCT \\
\hline $\begin{array}{l}\text { Ginandes } \\
\text { et al. } 2003\end{array}$ & $\begin{array}{l}\text { The authors conducted a randomized controlled trial in which eighteen healthy women under- } \\
\text { went the same surgical protocol of reduction mammaplasty at an ambulatory surgery practi- } \\
\text { ce. In postoperative care, patients were randomized and underwent three different treatment } \\
\text { conditions: standard care, } 8 \text { adjunctive supportive attention sessions, or } 8 \text { adjunctive hypno- } \\
\text { sis sessions targeting accelerated wound healing. The results of the study suggest a statisti- } \\
\text { cally significant acceleration of wound healing in the hypnosis group over other treatment } \\
\text { methods. }\end{array}$ & RCT \\
\hline $\begin{array}{l}\text { Barabasz } \\
\text { et al. } 2010\end{array}$ & $\begin{array}{l}\text { A total of } 26 \text { women took part in the study aiming to determine whether hypnosis can be } \\
\text { an effective tool for the treatment of lesions formed by human papilloma virus (HPV). The } \\
\text { participants had to self-select the method from either hypnosis or standard therapy. A total of } \\
13 \text { women selected hypnotherapy. The paper indicates that although in both groups there was } \\
\text { a decrease of the number and area of the lesions, in contrast to the medical therapy group } \\
\text { showing only } 1 \text { complete clearance, } 5 \text { of the } 13 \text { exposed to hypnosis therapy, regardless of } \\
\text { expectations for the outcome, showed complete clearance of lesions. Therefore the authors } \\
\text { highlight that after doing statistical calculations hypnosis therapy showed significantly better } \\
(p<0.0001) \text { wart clearance than medical therapy }\left(\chi^{2}=16.39, \mathrm{~d} f=1\right) \text {. }\end{array}$ & CT \\
\hline $\begin{array}{l}\text { Shakibaei } \\
\text { et al. } 2008\end{array}$ & $\begin{array}{l}\text { The trial was conducted to analyze the effect of hypnosis on both pain and re-experiencing of } \\
\text { trauma in burn patients. The randomized controlled trial was conducted on } 44 \text { patients hospi- } \\
\text { talized for burn care who were randomly assigned either to a hypnotherapy or a control group. } \\
\text { The effects of treatment were measured using a self-report numeric rating scale ranging from } \\
0 \text { to } 5 \text { in order to measure pain and the number of vivid, troubling events which patients could } \\
\text { recall during the } 24 \text {-hour period of study and it was checked in both groups at baseline, after } \\
\text { the } 3^{\text {rd }} \text { session, and after the } 5^{\text {th }} \text { session. The hypnotherapy group showed significantly lower } \\
\text { pain ratings than the control group and reported a significant reduction in pain from baseline } \\
\text { to the } 5^{\text {th }} \text { session. There was a significant reduction in trauma reexperience scores in the hyp- } \\
\text { notherapy group from baseline to the } 3^{\text {rd }} \text { session and from baseline to the } 5^{\text {th }} \text { session. }\end{array}$ & RCT \\
\hline
\end{tabular}

$R C T$ - randomized controlled trial, CT - clinical trial 
The inclusion criteria were fulfilled by 13 (Fig. 2 and Table 1).

\section{The present use of hypnosis}

The use of hypnosis in medical procedures was reported in areas of medicine such as oncology, orthopedics, pediatrics, surgery, psychiatry, dermatology, emergency medicine, gynecology, gastroenterology, and general medicine.

The use of hypnosis in such a popular general medicine condition as chronic headaches was reported by ter Kuile et al. (1994). Researchers studied 136 patients to find out if autogenic training (AT) and cognitive self-hypnosis training $(\mathrm{CSH})$ are valuable for chronic headaches. 40 of them received $\mathrm{CSH}$ treatment, 41 autogenic training and 53 a waiting list period. Headache intensity was measured using the headache index. There was a significant main effect of the pain intensity decreasing with the intervention $(F(124,2)=5.8, p=$ $0.004)$, but there was no significant difference between the form of therapies. The authors suggest that autogenic training is more manageable for day-to-day medical practice as its implementation to the treatment plan requires no special competence in comparison with $\mathrm{CSH}$. It was also highlighted by the authors that the efficacy of CSH may vary between the subjects as they can present different suggestibility and hypnotizability levels.

Another important work describing an effect of hypnosis in comparison with autogenic training is by Zitman et al. (1992). 79 patients were randomly assigned a therapy, either AT $(n=28)$ or future oriented hypnotic imagery (FI) $(n=27)$, and a therapist for the treatment of tension headaches. Moreover, in the second phase of the study, patients were presented the FI intervention as "hypnosis" (FI-H) $(n=24)$ to evaluate whether that would influence the efficacy of the method. For that intervention, FI-H, a new group of patients was formed. The improvement was assessed by self-report questionnaires and self-monitoring. Patients were asked to hourly report their pain intensity and their consumption of analgesics for 3 days during each week. During the assessment session research assistants presented the self-reporting questionnaire which included the State-Trait Anxiety inventory (STAI) and Self-rating Depression Scale (SDS). After pre-treatment and post-treatment assessment of patients the researchers found no significant difference between the therapies and therapists. In 66 patients who completed the 6-month follow-up period, there was a significant interaction effect between therapy and time on headache index score $(F(4,120)=3.31, p<0.05)$. Moreover, patients with FI-H intervention showed a greater reduction in their headaches compared to the pre-treatment assessment than the AT group. No significant differences in anxiety and depression were found between the therapy methods.

Montgomery et al. (2017) measured the impact of cognitive-behavioral therapy plus hypnosis (CBTH) on emotional distress in women undergoing breast cancer radiotherapy. In that randomized controlled trial, there were one hundred participants scheduled for 6-week external-beam breast radiotherapy who were randomly treated with CBTH for emotional distress control. The intervention group, $n=50$, was compared to the group treated with standard attention control (AC), $n=50$. The CBTH group received the initial 30-minute session - $15 \mathrm{~min}$ of CBT and $15 \mathrm{~min}$ of hypnosis. The patients also received a CBTH workbook at the end of the session and during the six weeks of radiotherapy they met with interventionists to receive a 15-minute session each week. The AC group received the same amount of time with the empathic interventionist as the CBTH group. The groups did not differ at baseline but at the midpoint of radiotherapy $(F(1,98)=7.16, p=0.009, d=0.53,95 \%$ CI: 0.13-0.93), at the conclusion of radiotherapy $(F(1,98)=10.33, p=0.002, d=0.64$, 95\% CI: 0.24-1.04) and in 4-week followup $(F(1,98)=10.71, p=0.002, d=0.65,95 \%$ CI: 0.25-1.05) there was a significant lowering in a short version of the Profile Mood States (SVPOMS) score in the CBTH group in comparison with the AC group. Furthermore, the $\mathrm{CBTH}$ group had lower Tension-Anxiety scores than the $\mathrm{AC}$ group at: the midpoint of radiotherapy $[F(1,98)=8.90, p=0.004, d=0.59,95 \%$ CI: 0.19-0.99], the conclusion of radiotherapy $[F(1,98)=7.52, p=0.007, d=0.54,95 \%$ CI: 0.14-0.94] and at the four week follow-up $[F(1,98)=34.67, p=0.001, d=1.30,95 \%$ CI: 0.50-2.11]. A similar effect was observed with the Depression-Dejection and Anger-hostility scores at the conclusion of radiotherapy $[F(1,98)=5.10, p=0.026, d=0.42,95 \%$ CI: $0.03-0.82][F(1,98)=7.10, p=0.009$, $d=0.53,95 \%$ CI: 0.13-0.93]. Scores did not differ between groups at the midpoint of radiotherapy $[F(1,98)=2.55, p=0.113, d=0.32$, 95\% CI: $-0.08-0.71$ for Depression-Dejection] $[F(1,98)=2.00, p=0.161, d=0.28,95 \%$ CI: $-0.11-0.67$ for Anger-Hostility] or at the 
four week follow-up $[F(1,98)=0.01, p=0.93$, $d=0.02,95 \%$ CI: $-0.37-0.41$ for DepressionDejection $][F(1,98)=0.06, p=0.80, d=0.05$, 95\% CI: -0.34-0.44 for Anger-Hostility]. Also, the groups did not differ at baseline. There was also a significant difference between the VigorActivity scores at: the midpoint of radiotherapy $[F(1,98)=4.09, p=0.05, d=0.22,95 \% \mathrm{CI}$ : $-0.18-0.61]$; the conclusion of radiotherapy $[F(1,98)=4.56, p=0.035, d=0.42,95 \% \mathrm{CI}$ : 0.03-0.82 ]; and at the four-week follow-up $[F(1,98)=4.36, p=0.039, d=0.41,95 \%$ CI: 0.02-0.81]. The Fatigue-Inertia scores were significantly lower in the CBTH group at the conclusion of radiotherapy $[F(1,98)=9.13$, $p=0.003, d=0.54,95 \%$ CI: $0.14-0.94]$ and at the four-week follow-up $[F(1,98)=14.73$, $p=0.001, d=1.30,95 \%$ CI: $0.50-2.11]$ than scores in the AC group. On the other hand, the Confusion-Bewilderment scores did not significantly differ between the groups over time.

A similar effect was reported by Schnur et al. (2008) where ninety patients presenting for excisional breast biopsy were randomly assigned to receive either a 15 -minute presurgery hypnosis session or 15-minute presurgery attention control session. Suggestions given in hypnosis involved increased relaxation and decreased distress and the control group of attention control involved nondirective empathic listening. Presurgery distress was measured by visual analog scales (VAS) and SV-POMS. The authors reported that postintervention and before surgery patients in the hypnosis group had significantly lower VAS emotional upset mean values (16.5 vs. $38.2, p<0.0001, d=.85$ ), VAS depressed mood (6.6 vs. 19.9, $p<0.02$, $d=0.67)$, and SV-POMS anxiety (10.0 vs. $5.0, p<0.0001, d=0.85$ ); and significantly higher levels for VAS relaxation (75.7 vs. 54.2, $p<0.001, d=-0.76$ ) than attention controls.

In the study conducted by Stalpers et al. (2005) 69 patients receiving radiotherapy (RT), mostly because of breast or prostate cancer, were randomly assigned to either the control group or intervention of hypnotherapy focused on decreasing levels of their anxiety and quality of life. Both groups were asked to fill in questionnaires regarding their anxiety and quality of life. Hypnosis intervention was administered after a brief interview with the patient 10 days before the stimulation. Then the first hypnotic induction took place immediately after the intake, the second before the simulation and the third before the first RT session. The fourth hypnotic session was administered at halfway through the RT course. The researchers found no statistically significant difference between the groups in terms of anxiety levels and quality of life $(p=0.96)$. The Mental and Physical Component score was measured. There was no significant difference in these scores $(p=0.582)$ between the hypnotherapy and control group. However, it is important to note that 17 of the $33(52 \%)$ patients in the hypnotherapy group stated that they improved their mental well-being $\left(\chi^{2} 0.95\right.$ $=22.319, p<0.05)$ in comparison with the control group, where none of them stated the same. 18 of the patients from the hypnotherapy group and 4 in the control group indicated an improvement in overall well-being $\left(\chi^{2} 0.95=\right.$ $17.916, p<0.05)$. All patients $(100 \%)$ in the hypnotherapy group would have recommended hypnotherapy to other patients.

In the important and broad work of Marc et al. (2008) a total of 347 patients were randomized and given anxiety and pain care, either standard or using hypnosis. Patients were women, aged 18-46, who were undergoing first-trimester pregnancy termination surgery. The group with the hypnosis session given, $n=172$, was treated by one of 2 certified hypnotists with standardized hypnotic intervention (SHI). This 20-minute hypnotic intervention provided the patient with suggestions to decrease pain intensity and unpleasantness. At the end of the surgical procedure, the patient was given the suggestion to end the hypnosis. The group with standard care given, $n=172$, stayed in the room with their relative or friend for $20 \mathrm{~min}$ prior the intervention, then went to the operating room with the family planning nurse, who provided the usual attention and support to the patient. During the surgery, the patient was equipped with a handheld button to signal the need for medication (either midazolam or fentanyl/both). In the hypnosis group, 63\% $(n=108)$ received medication (at least 1 dose), and in the standard care group, $85 \%(n=149)$ received medication (at least 1 dose). "The 22\% difference (95\% CI: $13-32 \%)$ in the use of medication was statistically significant, which means that 4-5 patients (number needed to treat, 5; 95\% CI: 3-8) would have to receive the SHI for 1 person to benefit from it and not require sedation during the procedure". The difference between pain in both groups met statistical significance (difference, $2.43,95 \%$ inferior CI: $-2.28,1$-sided $p=0.0048$, null hypothesis rejected). However, the difference in anxiety was not statistically significant. Therefore, it is worth noting that the researchers could not rule out a small in- 
crease in anxiety because of the novelty of the procedure. Overall the hypnoanalgesia intervention led to a $>20 \%$ decrease in the frequency of intravenous medication administration while maintaining clinically equivalent levels of pain and anxiety during the procedure.

Beneficial effects of hypnosis on oncology patients were also reported by Lang et al. (2008); after being randomized, 201 patients undergoing percutaneous tumor embolization received standard care, emphatic attention or self-hypnotic relaxation. The patients received a local anesthetic (2 $\mathrm{mg}$ hydromorphone s.c.). In the Emphatic Attention (EA) group the assistant displayed 8 standardized empathic attentive behaviors such as matching patient's verbal preferences, adapting to the patient's nonverbal communication pattern, listening attentively, providing perception of control, swiftly responding to the patient's requests, encouraging the patient, avoiding negatively-valued language and using emotionally neutral descriptors. In the Hypnosis Group the assistant also read a hypnosis script which suggested transforming potential discomfort into a sensation of warmth, coolness or tingling. The outcome was assessed every $15 \mathrm{~min}$ by the patient's self-report to the researcher of how they rated their comfort between 0 (no pain at all) and 10 (worst pain possible) and their anxiety between 0 (no anxiety at all) and 10 (terrified). Additional medication use of $50 \mu \mathrm{g}$ of fentanyl or $1 \mathrm{mg}$ of midazolam - 1 unit was also measured. The authors reported that anxiety decreased significantly in the hypnosis group compared to the standard group in the first 15-30 min (standard treatment: $n=68$, median $=3.0, \mathrm{IQR}$ [interquartile range $\left(25-75^{\text {th }}\right.$ percentile) $]=0-5$; hypnosis: $n=66$, median $=2.0 ; \mathrm{IQR}=0-4, p=0.016$ ). By $30-45 \mathrm{~min}$ anxiety in the hypnosis group was significantly decreased as compared to the standard and also empathy group (standard: median $=2.0$, $\mathrm{IQR}=0-4, n=69$; empathy: median $=2.0$, $\mathrm{IQR}=0-4, n=64$; hypnosis: median $=0.0$, $\mathrm{IQR}=0-3, n=65, p(\mathrm{SvsH})=0.015, p(\mathrm{EvsH})$ $=0.006$ ). Pain was significantly less for hypnosis than standard and empathy patients in the 15-30 and 30-45 min intervals (15-30 min - standard: median $=1.0, \mathrm{IQR}=0-3, n=68$; empathy: median $=1.0, \mathrm{IQR}=0-3, n=65$; hypnosis: median $=0.0, \mathrm{IQR}=0-2, n=66, p(\mathrm{SvsH})=$ $0.002, p(\mathrm{EvsH})=0.014,30-45 \mathrm{~min}-$ standard: median $=2.0, \mathrm{IQR}=0-4, n=69$; empathy: median $=1.0, \mathrm{IQR}=0-4, n=64$; hypnosis: median $=0.0, \mathrm{IQR}=0-2, \mathrm{n}=66, p(\mathrm{SvsH})=$
0.002, $p(\mathrm{EvsH})=0.004)$. Moreover, patients in the hypnosis group received significantly less medication $($ mean $=2.00, \mathrm{IQR}=1-4)$ than standard group patients (mean $=3.00$, $\mathrm{IQR}=1.5-5.0, p=0.0147$ ) and empathy group patients (mean 3.50, IQR $=2.0-5.9$, $p=0.0026)$, who did not differ from each other $(p=0.4505)$.

Hypnosis is also widely used in psychiatry, as can be presented by the paper of Abramowitz et al. (2008), who assessed the benefits of add-on hypnotherapy in patients with chronic posttraumatic stress disorder (PTSD). Thirty-two PTSD patients treated with SSRI antidepressants and supportive psychotherapy were randomized to 2 groups: 15 patients in the first group received zolpidem $10 \mathrm{mg}$ nightly for 14 nights, and 17 patients in the hypnotherapy group were treated with symptom-oriented hypnotherapy, twice-a-week 1.5-hour sessions for 2 weeks. After the duration of the therapy, there was a significant main effect in the treatment group, $F(1,30)=4.96, p=.034$, with PTSD symptoms as measured by the PDS being lower in the hypnotherapy group (HT) compared to the zolpidem group (ZT). This effect was preserved at follow-up 1 month later $($ mean $=31.5$, $\mathrm{SD}=9.9$ ). Given stress reactions there was an interaction between the treatment type and the assessment time, $F(1.4,43.3)=11.2, p<$ 0.0005 , indicating that intrusion and avoidance reactions decreased in the HT group but not in the $\mathrm{ZT}$ group. The authors reported that there was also a significant positive effect of hypnosis on decreasing depression, improving sleep in its overall score but also in quality and in decreasing the number of awakenings.

The use of hypnosis in pediatric cancer patients was reported by Liossi et al. (2006), who conducted a prospective controlled trial on 45 patients (age 6-16 years). In the study, they compared the impact on lumbar puncture-induced pain and anxiety of an analgesic cream (eutectic mixture of local anesthetics, or EMLA) with a combination of EMLA with hypnosis. For the purpose of comparison, patients were divided randomly into 3 groups: EMLA only, EMLA plus hypnosis, EMLA plus attention control. Measures were taken in the form of time 1-4 (T 1-4) as follows: T1 - baseline, T2 - therapist, T3 - self, T4 - self 2 . For the selfreported anticipatory anxiety at $\mathrm{T} 2$, there was no mean difference between the EMLA group and the EMLA attention group, $t(28)=0.00$, $p=1.00$, but there was a statistically significant difference between the EMLA hypnosis and 
the EMLA groups, $t(28)=14.86, p<0.001$; and the EMLA hypnosis and the EMLA attention groups, $t(28)=14.86, p<0.001$. At T3, the mean levels of anticipatory anxiety in the EMLA hypnosis group were significantly lower than those in the EMLA group, $t(28)=12.17$, $p<0.001$, and the EMLA attention group, $t(28)=13.60, p<0.001$. There was no significant difference between the EMLA group and the EMLA attention group, $t(28)=0.87, p=0.39$. These same conclusions were obtained at T4. A similar effect could be observed in procedurerelated self-reported anxiety levels, where at T2, the mean self-reported anxiety in the EMLA attention group was significantly lower than the mean in the EMLA group, $t(28)=3.63$, $p<0.001$, and there was a significantly lower mean for the EMLA hypnosis group compared with the EMLA group, $t(28)=10.14$, $p<0.001$; and for the EMLA hypnosis group compared with the EMLA attention group, $t(28)=6.88, p<0.001$. At T3, the mean level of anticipatory anxiety in the EMLA hypnosis group was significantly lower than the EMLA group, $t(28)=7.28, p<0.001$; and significantly lower than the EMLA attention group, $t(28)=7.10, p<0.001$. Also, at T3, there was no significant difference in the mean selfreported anxiety levels between the EMLA group and the EMLA attention group, $t(28)=1.02$, $p=0.32$. These same conclusions were drawn from the data at T4. Lastly, the procedurerelated self-reported pain showed a similar outcome in each instance, the mean level of procedure-related pain in the EMLA hypnosis group was found to be lower than that in the EMLA attention group: $\mathrm{T} 2, t(28)=4.12$, $p<0.001$; T3, $t(28)=4.75, p<0.001$; T , $t(28)=3.40, p<0.002$; and lower than that in the EMLA group: T2, $t(28)=6.17, p<0.001$; $\mathrm{T} 3, t(28)=6.15, p<0.001 ; \mathrm{T} 4, t(28)=4.88$, $p<0.001$. There was no difference between the EMLA and EMLA attention groups at any point in time: $\mathrm{T} 2, t(28)=0.23, p=0.82 ; \mathrm{T} 3$, $t(28)=0.23, p=0.82 ; \mathrm{T} 4, t(28)=0.23$, $p=0.82$. The results confirmed that patients in the local anesthetic plus hypnosis group reported less anticipatory anxiety and less procedurerelated pain and anxiety and that they were rated as demonstrating less behavioral distress during the procedure.

The use of hypnosis in orthopedic hand surgery was tried with the scope to measure pain perception, postoperative recovery, and therapeutic comfort. In the work of Mauer $e t a l$. (1999) 60 patients presented for hand surgery in Hand Service at the Ryder Trauma Center, Miami, Florida, where 30 of them were assigned to receive hypnotic treatment consisting of the 20-minute Rapid Induction of Analgesia (RIA) script modified to fit the present sample, context and research questions. The control group, $n=30$, received standard attention control care. There was a measure of Perceived Pain Intensity (PPI), Perceived Pain Affect (PPA) and State-Anxiety (SANX). Those variables were measured once a day for 3 additional days by a "blinded" recording person. Moreover, surgeons' rated patients' progress and development of complications by themselves but were absent while the interventions were carried out. All the staff, except the researchers, were "blinded" as to whether or not the intervention had been used on a patient they were caring for. The authors report that there were no differences between the groups on day 1. On following days, hypnosis group patients had reported lower PPA and PPI than control group for all 3 days posttreatment $\left(\eta^{2}=0.21\right.$ to 0.36 for PPA and 0.17 to 0.28 for PPI) and additionally lower SANX on day 4 (Day 2, $\eta^{2}=0.02$; Day 3, $\eta^{2}=0.07$; and Day $\left.4, \eta^{2}=0.09\right)$. As for surgical recovery, the hypnosis intervention group showed greater progress than the control group. "A repeated measures MANOVA performed on PROGRESI and PROGRES2 demonstrated significant between-groups effects for hypnosis, Hotelling's Trace $=0.2913$; exact $F(2,44)=6.41, p=$ 0.004 . Within-subjects tests were significant for Time 1, Hotelling's Trace $=0.2702$; exact $F(2,44)=5.94, p=0.005$, and Time 2 , Hotelling's Trace $=0.2228 ;$ exact $F(2,44)=4.90$, $p=0.012$ ". The authors suggest that their work shows not only the beneficial impact of hypnosis on perceived pain but also its significant influence on the process of healing.

Surgery, in general, can also benefit from the use of hypnosis for accelerated wound healing, as suggested by Ginandes et al. (2003). The authors conducted a randomized controlled trial in which eighteen healthy women underwent the same surgical protocol of reduction mammaplasty at an ambulatory surgery practice. In postoperative care, patients were randomized and underwent three different treatment conditions: standard care, 8 adjunctive supportive attention sessions, or 8 adjunctive hypnosis sessions targeting accelerated wound healing. Data for assessment of the outcome included clinical examinations and digitalized photographs that were scored with a wound assessment inventory. The results of the study suggest a statistically significant 
acceleration of wound healing in the hypnosis group over other treatment methods.

As suggested by Barabasz et al. (2010), hypnosis can also be an effective tool for the treatment of lesions formed by human papilloma virus (HPV) infection. A total of 26 women took part in the study. The participants had to self-select the method from either hypnosis or standard therapy. A total of 13 women selected hypnotherapy. The hypnotherapy group was first exposed to debunking myths about hypnosis, then hypnosis-like experience and finally the Stanford Hypnotic Susceptibility Scale, Form C (SHSS:C) was introduced using the standardized induction from the Stanford Hypnotic Clinical Scale (SHCS; Morgan and Hilgard 1975). The photographs of the lesions and surrounding area were taken before treatment, at 6 weeks and at 12-week follow-up. Gynecologists measured and made diagrams of lesions showing size, number, and location before and after treatment for all participants in all groups. The authors underline the fact that no significant differences between the intervention and control group in the number of lesions and the area were found (hypnosis group: mean $=130.53, \mathrm{SD}=191.00$; medical treatment group: mean $=126.84$, $\mathrm{SD}=193.64 ; t=0.048, \mathrm{~d} f=24, p>0.05$, $\mathrm{d} f=12, p<0.05)$. As for the results, the paper indicates that although in both groups there was a decrease of the number and area of the lesions, in contrast to the medical therapy group showing only 1 complete clearance, 5 of the 13 exposed to hypnosis therapy, regardless of expectations for the outcome, showed complete clearance of lesions. Therefore, the authors highlight that after doing statistical calculations hypnosis therapy showed significantly better $(p<0.0001)$ wart clearance than medical therapy $\left(\chi^{2}=16.39, \mathrm{~d} f=1\right)$.

Another study significant to numerous medical faculties was conducted by Shakibaei et al. (2008), whose purpose was to analyze the effect of hypnosis on both pain and re-experiencing of trauma in burn patients. The randomized controlled trial was conducted on 44 patients hospitalized for burn care who were randomly assigned either to a hypnotherapy or control group. The intervention of hypnosis involved suggestions to reduce pain and reexperiencing the trauma. It was delivered in sessions 1-5. The effects of treatment were measured using a self-report numeric rating scale ranging from 0 to 5 in order to measure pain and the number of vivid, troubling events which patients could recall during the 24-hour period of study, and it was checked in both groups at baseline, after the 3 rd session, and after the $5^{\text {th }}$ session. The hypnotherapy group showed significantly lower pain ratings than the control group and reported a significant reduction in pain from baseline to the $5^{\text {th }}$ session $(p<0.001)$. That is in contrast to the control group, where pain did not change significantly from baseline to the $3^{\text {rd }}$ session $(p=0.648)$ or from baseline to the $5^{\text {th }}$ session $(p=0.095)$. There was a significant reduction in trauma reexperience scores in the hypnotherapy group from baseline to the $3^{\text {rd }} \operatorname{session}(p<0.05)$ and from baseline to the $5^{\text {th }}$ session $(p<0.001)$ but not the control group $(p=0.53$ and $p=$ 0.617 , respectively).

\section{Discussion}

This is the first such broad and up-to-date analysis of the use of hypnosis in medicine. The presented material clearly demonstrates that the method widely considered as a form of charlatanry is actually a helpful tool for medical purposes. Results of a conducted systematic survey of the literature were gathered to become the foundation for further clinical trials in this area.

Having in mind that it is hard to change opinion and overcome prejudice, we wanted to present the most significant scientific data that will allow the reader to form his own insight into the topic.

The overall strength of evidence was assessed as high, although some studies included a very limited number of participants (Barabasz et al. 2010; Ginandes et al. 2003) and one was not actually randomized (Barabasz et al. 2010).

There is no doubt that we should educate both ourselves and our patients about what hypnosis is and how it can be administered in medicine. There is also a great need for further research in this field. It is necessary to examine and measure the effectiveness of hypnosis in all of the medical procedures where it is applicable as it would encourage other doctors to use it in daily medical practice (Fuhr et al. 2017; Downe et al. 2015; Bejenke and Jensen 2012).

We hope that after reading the text it is now clear for the reader that hypnosis is actually a measurable and usable tool for medical professionals and it should not be regarded as a useful alternative to common medical procedures. By gathering all of the data we have made both the foundation for further research and a knowledge base for any physician interested in the self-development of the patient-related skills. 
The main limitations of this study were the number of publications mentioning hypnosis in use in conventional medicine and clearly undernumbered patient groups. Therefore, it is necessary to conduct more meta-analyses and much broader clinical trials to assess all possibilities of hypnosis used in medicine. When a greater amount of high-quality papers is published, we will provide a broader and more comprehensive study on the same topic.

\section{How we can administer hypnosis in common use}

It is necessary to know that being hypnotized is not related to giving up control of oneself. It is rather learning new ways to control one's body and mind in which the hypnotizer is taking the role of the coach (Carlson et al. 2017; Terhune 2017).

Furthermore, it has been proven that hypnosis uses the same mechanism in producing sensory experiences as pharmaceuticals (Winkelman 2017).

Some researchers claim that we should not change the name of hypnosis as a medical procedure to any other than just "hypnosis" (Montgomery et al. 2013). In Poland, it is commonly known that hypnosis is treated as a form of entertainment and it should not be used in the medical environment, although the latest reviews claim that hypnosis is considered in a positive way by the patients (Krouwel et al. 2017; Graus 2014).

\section{Conclusions}

Overall, hypnosis is a powerful tool that can be used to provide patients the best possible environment for the process of healing. Examples of hypnosis use mentioned above should be a guide on where to seek possibilities of implementation of hypnosis in medical practice.

\section{Acknowledgments}

We give special thanks to Robert Bucki MD, $\mathrm{PhD}$ for the invaluable contribution to this work.

\section{Disclosure}

The authors declare no conflict of interest.

\section{References}

1. Abramowitz E, Barak Y, Ben-Avi I, Knobler H. Hypnotherapy in the treatment of chronic combat-related PTSD patients suffering from insomnia: a randomized, zolpidem-controlled clinical trial. Int J Clin Exp Hypn 2008; 56 : 270-280.
2. Barabasz A, Higley L, Christensen C, Barabasz M. Efficacy of hypnosis in the treatment of human papillomavirus (HPV) in women: rural and urban samples. Int J Clin Exp Hypn 2010; 58: 102-121.

3. Bejenke CJ, Jensen MP. Communication and hypnosis in high-tech medicine: a conversation between Christel J. Bejenke and Mark P. Jensen. Contemp Hypn Integrative Ther 2012; 29: 236-270.

4. Carlson LE, Zelinski E, Toivonen K, et al. Mind-body therapies in cancer: what is the latest evidence? Curr Oncol Rep 2017; 19: 67.

5. Downe S, Finlayson K, Melvin C, et al. Self-hypnosis for intrapartum pain management in pregnant nulliparous women: a randomised controlled trial of clinical effectiveness. BJOG 2015; 122: 1226-1234.

6. Elkins G, Barabasz A, Council J, Spiegel D. Advancing research and practice: the revised APA division 30 definition of hypnosis 2015.

7. Eskandari N, Wang ZJ, Dumont GA. A delayed functional observer/predictor with bounded-error for depth of hypnosis monitoring. J Clin Monit Comput 2017; 31: 1043-1052.

8. Fuhr K, Schweizer C, Meisner C, Batra A. Efficacy of hypnotherapy compared to cognitive-behavioural therapy for mild-to-moderate depression: study protocol of a randomised-controlled rater-blind trial (WIKI-D). BMJ Open 2017; 7: e016978.

9. Ginandes C, Brooks P, Sando W, et al. Can medical hypnosis accelerate post-surgical wound healing? Results of a clinical trial. Am J Clin Hypn 2003; 45: 333-351.

10. Graus A. Hypnosis in Spain (1888-1905): From spectacle to medical treatment of mediumship. Stud Hist Philos Biol Biomed Sci 2014; 48: 85-93.

11. Hammond DC. A review of the history of hypnosis through the late 19th century. Am J Clin Hypn 2013; 56: 174-191.

12. Hoeft F, Gabrieli J, Whitfield-Gabrieli S, Al E. Functional brain basis of hypnotizability. Arch Gen Psychiatry 2012; 69: 1064-1072.

13. Häuser W, Hagl M, Schmierer A, Hansen E. The efficacy, safety and applications of medical hypnosis: a systematic review of meta-analyses. Deutsches Ärzteblatt Int 2016; 113: 289-296.

14. Keuroghlian A, Butler L, Neri E, Spiegel D. Hypnotizability, posttraumatic stress, and depressive symptoms in metastatic breast cancer. Int J Clin Exp Hypn 2010; 58: 39-52.

15. Kihlstrom JF. Neuro-hypnotism: prospects for hypnosis and neuroscience. Cortex 2013; 49: 365-374.

16. Kroger W. Clinical and experimental hypnosis in medicine, dentistry, and psychology. Lippincott Williams \& Wilkins, Philadelphia 2008.

17. Krouwel M, Jolly K, Greenfield S. What the public think about hypnosis and hypnotherapy: A narrative review of literature covering opinions and attitudes of the general public 1996-2016. Complement Ther Med 2017; 32: 75-84.

18. Lang E, Berbaum K, Pauker S. Beneficial effects of hypnosis and adverse effects of empathic attention during percutaneous tumor treatment: when being nice does not suffice. J Vasc Interv Radiol 2008; 19: 897-905.

19. Liossi C, White P, Hatira P. Randomized clinical trial of local anesthetic versus a combination of local anesthetic with self-hypnosis in the management of pediatric procedure-related pain. Health Psychol 2006; 25: 307-315

20. Maldonado J, Spiegel D. Hypnosis. Psychiatry. John Wiley \& Sons, Ltd. 2015.

21. Marc I, Rainville P, Masse B, et al. Hypnotic analgesia intervention during first-trimester pregnancy termination: 
an open randomized trial. Am J Obstet Gynecol 2008; 199: 469.e1-469.e9.

22. Mauer M, Burnett K, Ouellette E, et al. Medical hypnosis and orthopedic hand surgery: Pain perception, postoperative recovery, and therapeutic comfort. Int J Clin Exp Hypn 1999; 47: 144-161.

23. Montgomery G, Sucala M, Dillon M, Schnur J. Cognitive-behavioral therapy plus hypnosis for distress during breast radiotherapy: a randomized trial. Am J Clin Hypn 2017; 60: 109-122.

24. Montgomery GH, Schnur JB, Kravits K. Hypnosis for cancer care: over 200 years young. CA Cancer J Clin 2013; 63: 31-44.

25. Morgan AH, Hilgard JR. The Stanford Hypnotic Clinical Scale for Adults. Am J Clin Hypn 1978; 2-3: 134-147.

26. Nash M, Barnier A. The Oxford handbook of hypnosis, theory, research and practice. Oxford University Press Inc., New York 2008.

27. Owen ARG. Hysteria, hypnosis and healing: the work of J.-M. Charcot. Garrett Publications 1971

28. Schiller F. Paul Broca, founder of French anthropology, explorer of the brain. University of California Press 1979.

29. Schnur J, Bovbjerg D, David D. Hypnosis decreases presurgical distress in excisional breast biopsy patients. Anesth Analg 2008; 106: 440-444.

30. Shakibaei F, Harandi AA, Gholamrezaei A, et al. Hypnotherapy in management of pain and reexperiencing of trauma in burn patients. Int J Clin Exp Hypn 2008; 56: 185-197.

31. Stalpers L, Da Costa H, Merbis M, et al. Hypnotherapy in radiotherapy patients: A randomized trial. Int J Radiat Oncol Biol Phys 2005; 61: 499-506.

32. Stern D, Spiegel H, Nee J. The Hypnotic Induction Profile: normative observations, reliability and validity. Am J Clin Hypn 1978; 21: 109-133.

33. Ter Kuile M, Spinhoven P, Linssen C, et al. Autogenic training and cognitive self-hypnosis for the treatment of re current headaches in three different subject groups. Pain 1994; 58: 331-340

34. Terhune DB. Metacognition of agency is reduced in high hypnotic suggestibility. Cognition 2017; 168: 176-181.

35. Tyrer SP. Psychology, psychiatry and chronic pain. Elsevier Science 2013.

36. Winkelman MJ. The mechanisms of psychedelic visionary experiences: hypotheses from evolutionary psychology. Front Neurosci 2017; 11: 539.

37. Wobst AHK. Hypnosis and surgery: past, present, and future. Anesth Analg 2007; 104: 1199-1208.

38. Zitman F, Van Dyck R, Spinhoven P, et al. Hypnosis and autogenic training in the treatment of tension headaches: A two-phase constructive design study with follow-up. J Psychosom Res 1992; 36: 219-228. 